\title{
A Comparison of the Modes of Inheritance of Diabetes in the Chinese Hamster and the KK Mouse
}

\author{
L. Butler and G.C. Gerritsen
}

Department of Zoology, University of Toronto, Canada and Diabetes Research, The Upjohn Company, Kalamazoo, Michigan, USA

Summary. The inheritance of glucosuria in the chinese hamster is controlled by four recessive genes. Any pair of these genes, when homozygous, will produce glucosuria. In addition to these, there are a number of modifier genes which control the severity, duration, and constancy of the glucosuria. In 18 of the 20 breeding lines reported in this paper the genetic background has been selected for optimum manifestation of glucosuria and the results fit the expectations. In the other two lines there is less uniformity, indicating that some modifiers are still segregating. Genotypes are postulated and it should now be possible to produce litters with $0 \%, 50 \%$, or $100 \%$ glucosurics. - The inheritance of glucosuria in the $\mathrm{KK}$ mouse is explained by a dominant gene with $25 \%$ penetrance and a recessive modifier which raised the penetrance to $75 \%$. The confirmation of the presence of a recessive modifier in the C57 stock awaits the outcome of backeross data which are presently being compiled. Glucosuria is confined mainly to males, and its expression is affected by environmental factors such as fighting and breeding.

Etude comparative de l'hérédité du diabète chez le hamster chinois et la souris $K K$

Résumé. L'hérédité de la glycosurie du hamster chinois est contrôlée par 4 gènes récessifs. Chez l'homozygote, n'importe quelle paire de ces gènes produit la glycosurie. $\mathrm{De}$ plus, il $\mathrm{y}$ a un certain nombre de gènes "modificateurs" qui contrôlent la sévérité, la durée et la fréquence de la glycosurie. - Chez 18 des 20 souches d'élevages étudiées, les conditions génétiques ont été choisies pour obtenir une manifestation optimale de la glycosurie, ce qui est confirmé par les résultats. $I 1$ existe moins d'uniformité dans les 2 autres souches, ce qui suggère que quelques kmodificateurs» conservent des propriétés de ségrégation. On postule l'existence de différents génotypes qui devraient permettre de produire des portées d'animaux ayant une proportion de $0 \%, 50 \%$ ou $100 \%$ de glycosurie. La transmission de la glycosurie chez la souris KK s'explique par la présence d'un gène dominant ayant une pénétrance de
$25 \%$ et d'un modificateur récessif qui augmente la pénétrance à $75 \%$. La confirmation de la présence d'un modificateur récessif chez la souche C57 doit encore attendre la compilation de résultats antérieurs. La glycosurie est avant tout présente chez les animaux mâles et son expression est influencée par des facteurs d'environnement tels que l'élevage et l'agressivité.

Vergleichende Untersuchungen zum Erbgang des Diabetes beim chinesischen Hamster und der $K K$-Maus.

Zusammenfassung. Die Erblichkeit der Glykosurie des chinesischen Hamsters hängt von 4 rezessiven Genen ab, von denen nur je 2 in homozygoter Form vorzuliegen brauchen, um zu manifester Glucosurie zu führen. Zusätzliche Gene scheinen die Schwere, die Dauer und die Regelmäßigkeit der Glucosurie zu beeinflussen. In 18 von 20 Zuchtlinien wurde versucht, zugunsten optimaler Manifestation zu selektionieren. Die Resultate entsprechen denjenigen die auf Grund der eingangs erwähnten Hypothese erwartet wurden. In den restlichen 2 Zuchtlinien scheinen noch zusätzliche genetische Einflüsse eine Rolle zu spielen. Die Definition von Genotypen basiert auf den erhaltenen Ergebnissen, welche es ermöglichen sollten, Würfe mit $0 \%, 50 \%$ oder $100 \%$ glucosurischen Tieren zu erzeugen. - Bei der KK-Maus scheint die Glucosurie auf ein dominantes Gen zurückzuführen zu sein, dessen spontane Penetranz von $25 \%$ durch ein rezessives modifizierendes Gen auf $\mathbf{7 5} \%$ gesteigert wird. Die Bestätigung der Existenz des rezessiven Modifikators bedarf noch der endgïltigen Auswertung aller Daten. Glucosurie ist hauptsächlich auf männliche Mäuse beschränkt und wird von Umweltsfalstoren wie Aggressivität und Haltung beeinflußt.

Key-words: Diabetes in animals, chinese hamster, cricetulus griseus, inbred strains of mice, KK mice, inheritance of diabetes, diabetes genetics, polygenic inheritance of diabetes.
In this study of the inheritance of diabetes it was early apparent that no one criterion could be used to characterize diabetes. In the KK mouse we have used glucosuria, glucose tolerance, plasma insulin, blood sugar, polyuria, and body weight. There is a correlation between these criteria, but no one criterion or combination of these was definitive in classifying mice as "diabetic". Furthermore, we could not be certain that diabetes was a genetic entity, and for these reasons we settled on glucosuria as our criterion. For similar reasons, Gerritsen et al. (1969) decided to concentrate on glucosuria in the chinese hamster. Glucosuria is intermittent in both mice and hamsters; therefore the frequency of testing and age of onset both influence the classification of animals as glucosurics or non-glucosurics. Environmental factors such as feeding and caging also affect the classification. In the KK mouse normally only males are glucosuric. Harris (1969), found that if several males were caged together and began to fight they rarely became glucosuric. Also she showed that if a male was caged with a breeding female he rarely showed glucosuria. Because of these environmental effects some potential glucosurics are classified as normal. By standardizing the environment as much as possible we were able to classify the mouse colony in Toronto and the hamster colony at Kalamazoo. As the result of preliminary classification certain breeding procedures were employed and the progeny from these classified to show the pattern of inheritance. The result of the studies with the hamster was reported at the previous workshop (Butler, 1967), and indicated that there were four recessive genes operating. Any 
pair of these genes when homozygous could cause glucosuria. We now have further evidence for this scheme along with the suggestion that when an animal is homozygous for three genes it becomes ketotic. It is easily apparent to anyone trained in genetics that this is not the only scheme of inheritance which would explain the data, in fact, somewhat similar data from the KK mice is interpreted by an entirely different method. It is the purpose of this paper to present the data for both the chinese hamster and the KK mouse, and to show the strength and weakness of the mode of inheritance of glucosuria postulated for both.

First it is necessary to clarify the meaning and the implications of the genetic terms we intend to use. The simplest case is monogenic (one gene) inheritance where three situations may occur. The trait may be dominant, in which case it will appear in all generations and cannot appear in the offspring unless it is in at least one of the parents. When both parents are diabetic then either all or three quarters of the offspring will be diabetic. If only one parent is diabetic then either all or one half the offspring will be diabetic. When neither parent is diabetic then none of the offspring should be diabetic. Turning next to the second situation where the trait is the result of a recessive gene, then if both parents are diabetic all offspring will be diabetic. If one parent is diabetic then one half or none of the offspring will be diabetic. And if neither parent is diabetic then either one quarter or none of the offspring are diabetic. It is easy to distinguish between these two situations but the third situation of reduced penetrance modifies most of these statements. Penetrance not only changes the ratios expected but also means that there is no class which breeds true. The term penetrance implies that although the causal gene is present in the correct dosage, not all individuals show the expected phenotype. Penetrance is an operational statistical term which records the number of individuals showing the trait as a percentage of those expected to show the trait. For instance, if diabetes was inherited as a recessive, then the cross of two diabetics should give $100 \%$ diabetics but penetrance could modify this to give any value between 10 and $100 \%$. Reduced penetrance can be caused by interaction with the genetic background (modifiers) or by environmental effects on the physiological pathway between gene and phene. If reduced penetrance is genetic, then selection for appropriate modifiers will permanently increase this penetrance. Whereas if the penetrance is under environmental control, then changes in the environment such as feed composition or temperature will cause temporary fluctuations in penetrance.

A more complex type of inheritance than the simple monogenic is when there are more than two alleles at one locus. This multiple allelic system was not considered in this case since in hamsters and $\mathrm{KK}$ mice all individuals are closely related to the first diabetic which was discovered. Neither was sex linkage considered, as no evidence of criss-cross inheritance shows in these pedigrees. Rules for two genes, three genes, or four genes can be given but it must be pointed out that if penetrance is included these schemes tend to become unworkable. It can be seen that if penetrance has a strong genetic component, then monogenic with reduced penetrance or monogenic with modifiers is the same as multigenic. An even more complex type of inheritance is polygenic. Here a number of genes are necessary to bring about a certain trait. It is implied that these genes are all acting on the same system and that a certain number of these must be present to produce sufficient hormone or other substance to reach the threshold. For instance, if there were ten polygenes for the production of insulin and seven were required to produce enough to reach the threshold, then any individual with six or less of these genes would normally be diabetic. However, the environmental effects would be such that an individual with genes producing close to the threshold would sometimes fall into one class and sometimes into the other.

In both hamsters and mice there are difficulties in classification especially in deciding which animals are normal. If all glucosuria tests are negative then one has to decide whether the tests have been given frequently enough to detect transient glucosuria, or whether the animal has a delayed onset and has not reached the proper age. Arbitrary decisions can be made on this point and the pedigree data plotted and examined. When this is done, it reveals that neither species gives a distribution which fits a simple monogenic scheme. In both cases, one has to invoke penetrance, modifiers, or several genes, and this means that until definitive crosses are made, there are several schemes which fit the data equally well. With this in mind, let us look at the latest data for the KK mouse.

The data for the $\mathrm{KK} \times \mathrm{C57}$ mouse are given in Table 1. Most of these data are from Harris (1969) who attempted to test these animals at weekly intervals from weaning to ten months of age. It is evident that the KK strain, in spite of forty generations of inbreeding, is not $100 \%$ glucosuric. It is also evident that the $F_{1}$ contains as high a percentage of glucosurics as the $P_{1}$, which suggests that we are dealing with the product of a dominant gene. The $F_{2}$ also contains about the same proportion of glucosurics, and the simplest scheme for these three generations is a dominant gene with $25 \%$ penetrance in the males. The fourth column shows the expected percentage based on this scheme and it can be seen from the chi squares that it fits the expectations for the first four values. In the $F_{3}$ two types of crosses were made. The gene at this time had zero penetrance in females, therefore these were phenotypically normal, and they were crossed with either a glucosuric or a normal male. The proportion of glucosurics from these two crosses is clearly different, and while the cross $\mathrm{N} \times \mathrm{N}$ fits the expectation, the cross $\mathrm{N} \times \mathrm{D}$ does not. Furthermore the data for subsequent generations does not fit this scheme because the percentage glucosurics cannot exceed $25 \%$ unless we 
change the penetrance. If penetrance must be changed in later generations then since the feeding and caging have not been changed, there must be a genetic component; another gene or genes which act as modifiers. If we accept this, then the next more complex scheme is to postulate a recessive modifier which is present in the C57 parent. This oan be rationalized in an evolutionary manner by assuming that when the mutant for diabetes occurred in the ancestors of KK it was almost $100 \%$ penetrant, but that natural selection has incorporated a dominant modifier into the stock which has reduced the penetrance to $25 \%$. The unrelated C57 stock does not have this modifier but carries the recessive alleles instead. Another way of rationalizing this is that observations show that KK mice are prone to fighting and whisker-chewing which results in noticeable damage to the skins of these mice. Mice which fight are rarely glucosuric.

C57 mice do not fight when eaged under our conditions. The selected progeny of these two strains in the $F_{4}$ to $F_{6}$ do not fight. So we can postulate that the modifier gene when dominant encourages stressful
The data for the mode of inheritance of diabetes in the Chinese hamster are given in Butler 1968, and will not be repeated here. In this paper we shall concentrate on 20 males and their progeny (Table 2). These males were selected because they had large numbers of progeny which had been adequately tested over a long period of time. In the previous study any animal which had two or more Testape values of $+\mathbf{2}$ or higher, was classified as diabetic. Animals with +1 's or only one +2 or higher were classified as trace. In order to assess the degree of glucosuria and its consistency a simple index was used in this study. The animals were tested twice monthly beginning with the third month and ending with the twelfth. These twenty values were summed and divided by the number of tests to give an index which by its magnitude measures severity, earliness of onset, and constancy of the test. To classify the animals as diabetic or normal, the pivot index of 1.0 was chosen. Hamsters with an index 1.0 or more were called diabetic, and an examination of their individual records shows that they would have been so classified by the previous criterion. Of the 537 offspring

Table 1. Distribution of glycosuria in various generations of mice from the cross $K K X C 57$

\begin{tabular}{|c|c|c|c|c|c|c|c|}
\hline & \multicolumn{2}{|l|}{ Number } & \multirow[b]{2}{*}{ Observed } & \multicolumn{2}{|c|}{ Expected } & \multicolumn{2}{|c|}{ Chi squares } \\
\hline & Normal & G.U. ${ }^{a}$ & & 1 gene & 2 genes & 1 gene & 2 genes \\
\hline$P_{1}(C 57)$ & 42 & $\mathbf{0}$ & $0 \%$ & $0 \%$ & $0 \%$ & & \\
\hline$P_{1}^{1}(K K)$ & 52 & 14 & $21 \%$ & $25 \%$ & $25 \%$ & 0.5 & 0.5 \\
\hline$F_{1}^{1}$ & 20 & 7 & $26 \%$ & $25 \%$ & $25 \%$ & 0.01 & 0.01 \\
\hline$F_{2}^{\prime}$ & 194 & 47 & $20 \%$ & $19 \%$ & $28 \%$ & 0.05 & $8.6^{\mathrm{b}}$ \\
\hline$F_{3}^{2}(N \times N)$ & 137 & 28 & $17 \%$ & $18 \%$ & $22 \%$ & 0.13 & 2.5 \\
\hline$(N \times D)$ & 122 & 99 & $45 \%$ & $21 \%$ & $44 \%$ & $75.2^{\mathrm{b}}$ & 0.05 \\
\hline$F_{4}$ & 53 & 52 & $50 \%$ & $23 \%$ & $49 \%$ & $41.6^{\mathrm{b}}$ & 0.01 \\
\hline$F_{5}$ & 19 & 40 & $68 \%$ & $25 \%$ & $65 \%$ & $57.6^{\mathrm{b}}$ & 0.2 \\
\hline & 17 & 46 & $63 \%$ & $25 \%$ & $70 \%$ & $77.5^{\mathrm{b}}$ & 0.3 \\
\hline$B K(K K)$ & - & - & - & $25 \%$ & $25 \%$ & & \\
\hline$B C(C 57)$ & 一 & - & - & $12 \%$ & $25 \%$ & & \\
\hline
\end{tabular}

a G.U. = glucosuric

b Highly significant.

N.B. Expectation for one gene assumes a dominant $\mathrm{K}$ with $25 \%$ penetrance. Expectation for two genes assumes $\mathrm{K}$ - $\mathrm{A}$ - has $25 \%$ penetrance and $\mathbf{K}$ - aa has $75 \%$ penetrance.

fighting, and the recessive, by suppressing this habit, increases the penetrance of glucosuria. Irrespective of the mechanism, the scheme would give the expectations listed in column five of Table 1 . It can be seen from this table that the percentages calculated for the two gene hypothesis in which $\mathrm{K}$ has $25 \%$ penetrance and $a a$ has $75 \%$ penetrance, gives a good fit in all cases except one. This is in the $F_{2}$ where the expected was $28 \%$ compared with an observed of $20 \%$. In this generation the mice were not tested as frequently and glucosurics may have been missed. It should be noted that under the first hypothesis the percentage glucosurics cannot exceed $25 \%$ and under the second hypothesis it cannot exceed $75 \%$. The major test of the two gene hypothesis will come when enough backcross data have been collected. listed in Table 2, 288 were classified as diabetic. The 249 hamsters with indexes of less than 1.0 include trace or mildly diabetic animals as well as normal ones. Examination of the individual records of this group shows that 39 of them would have been elassified as diabetic by the old criterion of two plus 2's or higher at any time in their life. Several of these did not become diabetic until after they were one year old, in fact, two were twenty two months, and one 28 months before they gave positive tests. Two other had two +3 tests at two months of age and all negative from then on. It is interesting to note that 19 of the 39 animals which are diabetic by the previous test but not by the index method, come from three closely related lines. Z $01-08$ had 16 animals which had indexes of $<1.0$ but 8 of these were diabetic by the previous method, whereas $\mathrm{W} 01-04$ 
had only 1 new diabetic out of 31 animals with indexes of $<1.0$. This indicates quite strongly that the constancy or irregular nature of glucosuria depends on the genetic background of the particular line. Hamsters with an index of 4.0 or more are ketotic. The numbers given in the penultimate column of Table 2 are the number of animals in each cross which had two positive ketostix tests.

In Table 2 the males are arranged in order of ascending index values and it will be seen that, with few exceptions, the mean index value of the offspring (last cate that $P G 06-01$ and his sisters (mates) were of the genotype a aBb which would give an expected of 2 . Male $\mathrm{U} 07-01$ is a little unusual in that it produced a ketotic, the probability of occurrence of which is only 1 in 64 . The average indexes for these crosses are low as expected. In the remainder of the crosses the number of diabetios fits the expected except in three cases. These are: Z $01-08$ which is six diabetics short and has a chi square of $5.7 ; Z 01-01$ and $W 01-07$ which have three and fifteen normal animals respectively when all should have been diabetic.

Table 2. The index of glycosuria, the frequency of diabetics and ketotics, and the genotypes of certain crosses of the chinese hamster

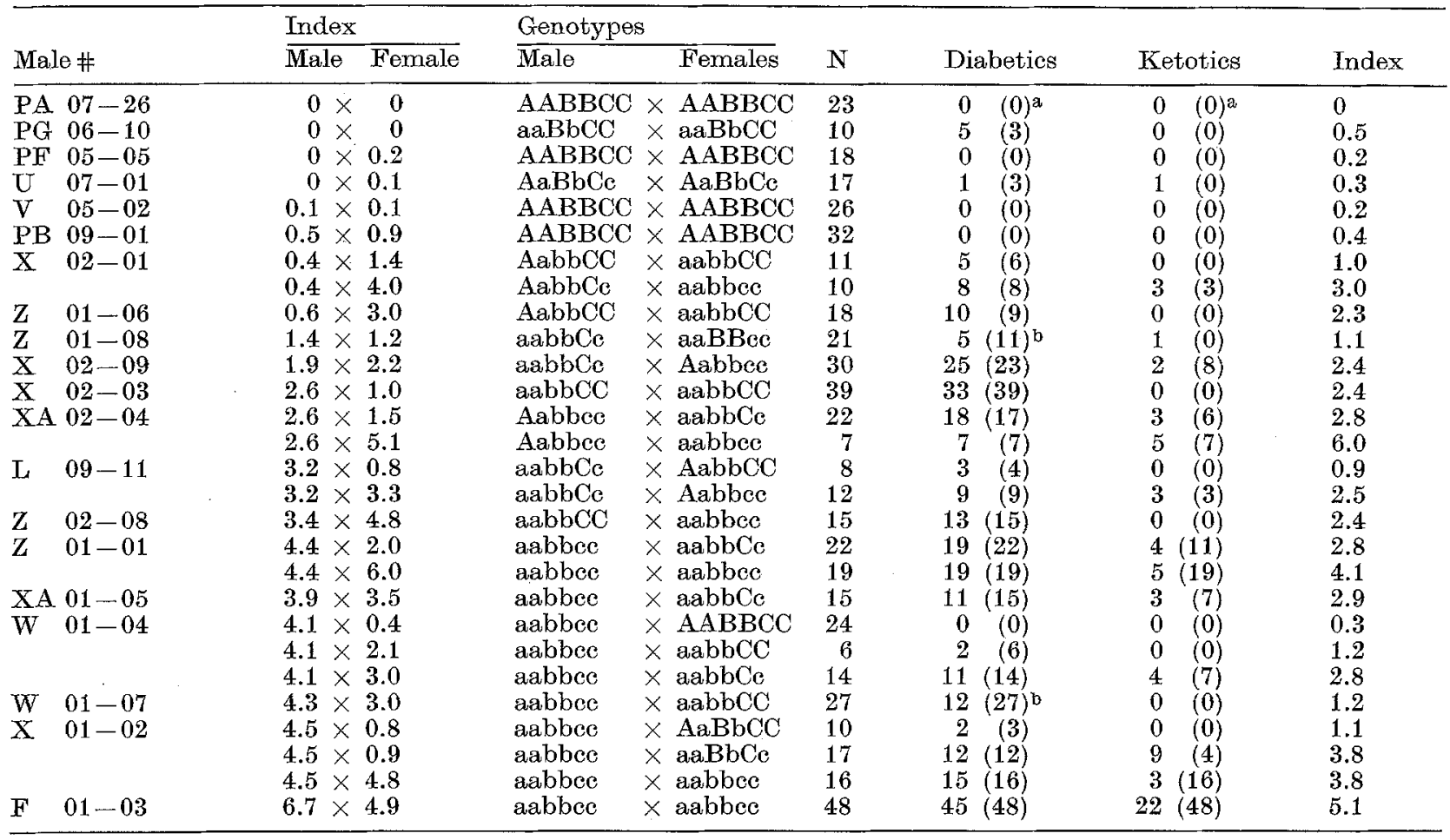

a The figure in brackets is the number expected from the genotype postulated.

b Difference is statistically significant.

column) increases in the same manner. In most cases the offspring of one male and several females are grouped together and the average index value for these females is given. In a few cases, there was marked. heterogeneity between the offspring of different females and these cases are listed separately. Each male and female is given a genotype which is consistent with its phenotype and its breeding behaviour. Only three genes are specified as it is only necessary to consider a fourth gene in two crosses. It is expected that in most cases DD could be added to the postulated genotypes.

The first six matings listed in Table 2 all represent crosses between normal (non glucosuric) animals and we find that of the 126 offspring produced only four were glucosuric. Three of these were from one cross and indi-
The offspring of Z $01-08$ have already been mentioned as an atypical case where 8 hamsters had indexes of less than one but did have two positive Testape values greater than +2 . It is evident that in this particular line the glucosuria is not as severe as in other lines, and that the difference between the observed and expected is a matter of classification. In Z $01-01$ of the three exceptional animals which were classified as normal, two would have been classified as diabetics by the previous criterion; thus, there appears to be misclassification of these three animals. In the cross W $01-07$ we expected all 27 offspring to be glucosuric and 15 were not. Two of these 15 could have been reclassified by the $2 \times 2+$ criterion but not the others. It was for cases similar to this that the four gene hypothesis was 
first postulated for if we rewrite the genotypes as aabbceDD $\times$ aaBbCCdd, then the number of glucosurics expected is 13 which is an excellent fit.

In most cases the number of ketotics is significantly less than the number expected under the hypothesis of homozygosity of three recessive genes; and we must conclude that either this hypothesis is wrong, or there is a penetrance factor. To satisfy this hypothesis we must postulate a penetrance factor of $50 \%$ and it would seem that a large part of this penetrance is the result of genetic modifiers. If this is so, then it will be possible to select lines which will breed true for ketosis.

\section{References}

Butler, L.: The inheritance of diabetes in the Chinese Hamster. Diabetologia 3, 124-129 (1967).

Gerritsen, G.C., Needham, L.B., Schmidt, F.L., Dulin, W.E.: Studies on the prediction and development of diabetes in the offspring of diabetic Chinese Hamsters. Diabetes 18, 334-335 (1969).

Harris, M.J.: The diagnosis and inheritance of diabetes mellitus in KK mice. University of Toronto: Ph. D. thesis 1969 .

Dr. L. Butler

Dept. of Zoology

University of Toronto

Toronto, Ontario, Canada 